\title{
Sciendo
}

\section{COVID-19 and mass-media: the weight of the words}

\author{
Diana Spulber \\ Peoples' Friendship University of Russia, Moscow, Russian Federation \\ email: spulber_d@pfur.ru
}

DOI: $10.2478 /$ gssfj-2020-0012

\begin{abstract}
The events of the year 2020 have had and heavy impact on the whole world. For the first time, each of us felt that we were part of this great globalised family. For the first time, the events that happened on a strict continent were directly related to other continents' inhabitants. The new words entered to be a part of our vocabulary, and the new way of behaviour have been performed. On the positive side, we could mention that countries have been discovered for people with low geographical culture and the existence of certain professions and certain hospital departments have been discovered. The role of mass-media has been decisive in transmitting the news about Covid 19 in various ways. The article aims to show the role of mass media on the headlines of high ranking newspapers in UK Germany and Italy by analysing the weight of the words. The used methodology was the analysis to analyse the headlines of high ranking newspapers in UK Germany and Italy. Through content analysis, it was possible to individuate how the news-papers attract the audience through the headlines and how they contributed to keeping up the attention and the stress among social reality.
\end{abstract}

Keywords: Covid-19, mass- media, communication, the weight of the words

\section{Introduction}

The 2020 year has been characterised by one event - the pandemic, the most important actor of our social reality was the virus Sars-CoV-2 or so-called Covid -19 or Coronavirus. If we check in words, the 2020 year we can identify some paradigm that took communication stage. These words are Covid -19 or Coronavirus, pandemic, epidemic, quarantine, lockdown, infodaemia, zoonosis, virologist lockdown, social distance and masks. Let have got a window back into the beginning of 2020 to understood how these words became mostly pronounced:

- 31 December China made a report about a cluster of pneumonia cases with unknown aetiology later this pneumonia has been identified as a new coronavirus SARS CoV-2 or Covid-19.

- 9 January 2020, the World Health Organization (WHO) has declared the emergency of public health of international interest in the epidemic of Coronavirus in China. 
- 24 January - first case of Covid -19 reported in France a case connected with travel in China

- 28 January - first case of Covid -19 reported in Germany a case connected with travel in China

- 30 January, the Istituto Superiore di Sanità (ISS) confirmed the first two cases of COVID-19 infection in Italy and on 21 February confirmed the first Native case in Italy.

- 30 January the World Health Organization (WHO) declare an epidemic situation

- 11 March 2020, the World Health Organization (WHO) declares a global pandemic of COVID-19.

After this data, all the countries should perform the precautionary measures taking into account the widespread nature of the epidemic, proclaimed a state of emergency, and put the first measures to contain the entire territory's contagion. But let's take two steps more and in particularly

- On 25 March 2020, more than 150 countries worldwide reported the cases of Covid-19, the data shows the high contagious spread of the SARS CoV2.

- On 3 April 2020, the number of confirmed COVID-19 cases reported worldwide surpassed one million. This number will increase to 10 million on 29 June 2020 and till 20 million in August till to arrive at 60 million reported cases of SARS CoV-2 on 26 November.

Now let see how the words have been started to be a part of our routine. Once the first cases for Covid-19 have been reported in China and became public the first question was about the origin of this Virus. By this way, the roonosis became a paradigm of our vocabulary as it was discovered that this Virus came from animals and have been transferred to the humans the provenience of the Virus has been connected with live animals market "Wuhan's Huanan Seafood Wholesale Market". After the analysis of the reported data from China and form other Countries on 30 January the WHO declares that:

"detection of 2019-nCoV in an animal (including information about the species, diagnostic tests, and relevant epidemiological information) should be reported to the World Organization for Animal Health (OIE) as an emerging disease. Countries should place particular emphasis on reducing buman infection, prevention of secondary transmission and international spread, and contributing to the international response though multi-sectoral communication and collaboration and active participation in increasing knowledge on the Virus and the disease, as well as advancing research." (https://www.who.int/news/item/30-01-2020-statement-on-the-second-meetingof-the-international-health-regulations-(2005)-emergency-committee-regarding-theoutbreak-of-novel-coronavirus-(2019-ncov)

Seeing the Virus's high spread level among the countries and continents the notion of the epidemic entered in all homes after a short time on the beginning of the March to the epidemic was added a new one pandemic. According to the WHO data on 20 January, Covid 19 have been reported from Thailand, Japan, South Korea and 24 January from France. Tedros Adhanom Ghebreyesus the Director of WHO made a twit on 11 March 2020 "In the past two weeks the number of cases of Covid-19 outside China bas increased 13 fold \& the number of affected countries has tripled. There are now 
more than 118,00 cases in 114 countries, \& 4,291 people have lost their lives ... We have, therefore made the assessment that Covid 19 can be characterised as a pandemic" (https://twitter.com/WHO/status/1237777021742338049?s=20). The citizens of the entire world gotten acquainted with the difference between epidemic and pandemic. For the first time, the citizens felt as a component of one village. For the first time, the events that happened in one continent were an object on interest to other continents' citizens. The words epidemic and pandemic use, evocated in the collective memory the events of Spanish Flue that from 1918 to 1920 have made 50.000.000 victims and gave way to comparing the two pandemics with their differences and similarities.

The paradigm lockdown entered into our house by the news that in the Wuhan City was declared the lockdown. On 23 January 2020, with the declaration of a lockeddown city, circulation in and from Wuhan has been prohibited and also the circulation inside the city was restricted (Zhanwei Du1, Lin Wang1, Simon Cauchemez, et al., 2020). The word lockdown weight has increased after 9 March when the lockdown has been declared in Italy and later Spain, Austria, France and other European countries. The figure 1 shows that only ten European countries introduced the lockdown restriction. The benefits or the harm of lockdown has been discussed even in the countries where lockdown was not introduced. The paradigm of lockdown, the paradigm of social distancing, has been introduced in our vocabulary and for the first time that stays physically distancing is safe.

The quarantine and self-isolation paradigm appears in our vocabulary, together with lockdown and social distance paradigms. The quarantine paradigm evokes history again the fourteenth century as it derives from forty days, the typical duration of the isolation to which were subjected the ships that came from areas affected by the plague. Quarantine in this period meant the isolation of fourteen days firstly, it was as the self-isolation of the people that come from outside, and by the time it was not only a voluntary quarantine but imposed quarantine with different rules per countries, and by the time it was reduced from fourteen days to one week. 


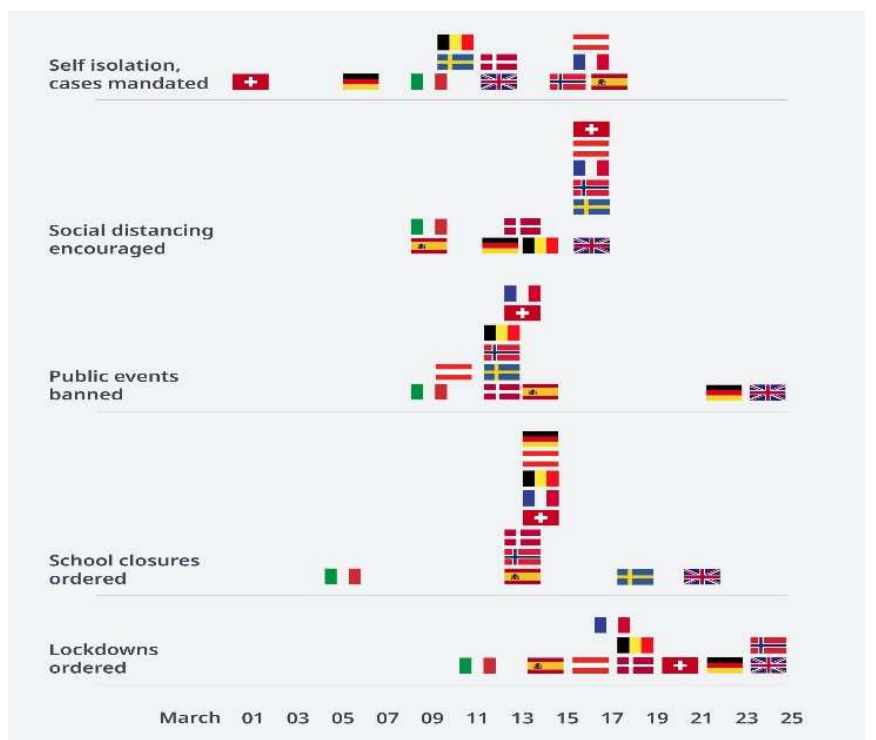

Figure 1 National Restriction in European countries (Source Imperial College London data)

The month of the March was characterised by another event -using the mask. The race to buy the mask, and the lack of masks was another peculiarity of this month. The "mask" paradigm and the mask as an object started to be a part of our lives: the first questions and confusing replies from WHO has created a confusional behaviour among individuals. The first indication was about using the mask; who should use the mask and later in different countries, and it became compulsory. The mask was also linked to the panic situation doing to the lack of the surgical mask. If we analyse the events, we can see how the use of the mask has been imposed in China and later in other countries as the WHO, and it was unclear whether it was unclear who should wear the mas and where is necessary to wear the mask.

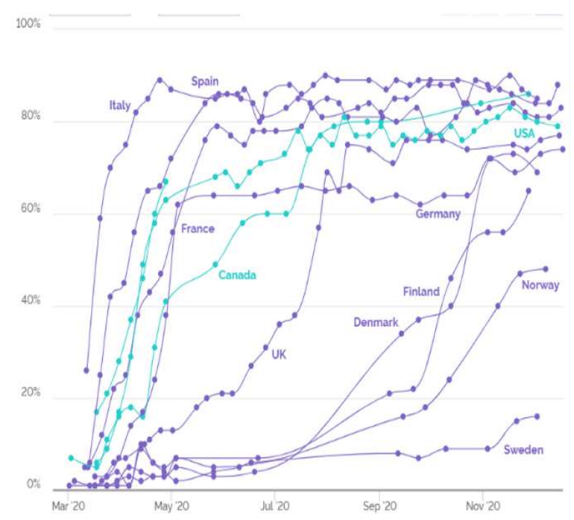

Americas and Europe

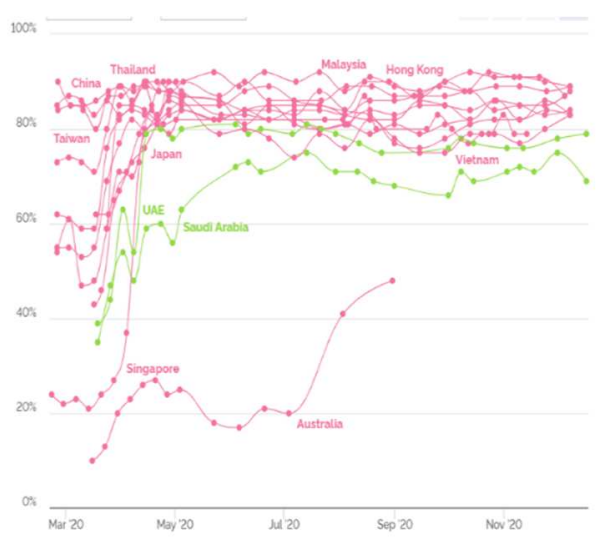

Asia/Pacific and Middle East

Figure 2 YouGov Covid -19 behaviour changes tracker: Wearing the mask when in public spaces period March December 2020 (source: author elaboration from YouGov data) 
Analysing the data of Americas and Europe that are shown in the figure 2 we can see how the wear of the mask increased in the period of the march month with the exception of Nordic countries, in fact, the countries like Denmark Finland has had an increasing percentage of wearing the mask on period September -November with the exception of Sweden where the wear of the mask in public spaces remains less than $20 \%$ of people. In Asiatic / pacific and Middle East countries the wear of the mask percentage is really high more than $80 \%$ in China Thailand Malaysia Hong Kong with a radical increase of wearing the mask in Singapore from $22 \%$ at the beginning of march month to $85 \%$ at the beginning of April month in one month the percentage of people wearing the mask was $63 \%$.

The $60 \%$ represent the difference of people who were not used to wearing the mask before Coronavirus period. The countries like China, Vietnam and Thailand the wearing mask was used before Covid -19 because of air pollution in fact from the figure 2 the Asia Pacific and the Middle East is possible to see how the percentage of wearing the mask was high at the beginning of March and kept the same position for all period.

All this data show how the routine life the behaviour has changed during the Coronavirus and what was the social-psychological land the social ground where the news could have a greater impact because it finds a social reality already proven by the changes in place to stem the spread of the Covid 19 virus. The changes of behaviours, the change of a daily routine the impossibility to move the insecurity in the future are factors that have put a strain on psychological resistances and have consumed individuals' biopsychosocial resources.

\section{Mass-media and the weight of the words: Theoretical background}

According to McLean, we are living in globalised village thanks to the evolution of new technologies of communication. The circulation of the news has had an increased impact during the pandemic, the events in China has had a direct audience impact on Europe for example even the China physically is on the other side of the Earth's hemisphere, the Italian Bergamo province event have been translated in every part of the world.

The mass-media largely contributes to fixing modes of thinking, largely determining ideas, habits and Customs. The mass- media have somehow become the "judges of truth", they decide and dictate fashion, consumption, ways of life. They establish what is right and what is wrong, and decide what the important and significant events in the world are.

The used words on describing the events around the world have a power of which some time is ignored the meaning and impact they cause on the subconscious of others. The words can be some time very heavy, very rough, and can cause so much harm around. Words have so much consequence that if we were really conscious, we would not speak. And here we can cite Ludwig Wittgenstein: "What we can not talk about we must be silent". Ludwig Wittgenstein, philosopher of the Twentieth Century (1889-1951) and father of the theory of language games have recognised the importance of the word, of the proposition, in which every element is the word with its own existence. His greatest work, Tractatus Logico-Philosophicus, he states that 
Geopolitical, Social Security and Freedom Journal, Volume 3 Issue 2, 2020

"a proposition shows its meaning. If the proposition is true, the truth is obvious." and by this sentence, he emphasises the importance of speech and its impact. The paradigms have two characteristics rational and emotional, the rational side is represented by the purely significant and the emotional side is represented by the emotive status that it can generate. this side There is a balance constantly between these two qualities and it depends on the particular situations. According to Fauconnier "the language we see is just the tip of the iceberg of the invisible process of creating meaning that takes place when we think and speak" (Fauconnier,1997). Communication is a process with a connection between sender of the message end the receiver of the message the rational coding of the message depends of the language or de-codification system is used as by sender as by receiver. The emotional coding of the message can have different recodification system and the sender intent cannot be de-codificated in the same way by the receiver, the emotional decodification or recodification system depends of a lot of subjective factors: the intensity of the words, the situation the environment, the emotional status of the receiver and so on. Heidegger shares that "language is the house of being" and proposes that to develop a language of its own, depends on the person that communicates what he wants to say, but does not communicate necessarily the meaning of what the other understands. By this way the communication problems appears. A. Binet states that every thought is initially born in the form of an emotional image (Binet 1946) S. Pinker expresses that there are micro-classes of words within a language, each with a life of its own, and together contribute to the construction of concepts that at a certain point can be considered to be prejudice, no matter how unconscious, or preconceptions simply accepted as truth. The mass-media, the social media cover individuals 24 x24 hour with news, sometimes this news can be perceived as negative factors to the individual health and the capacity of emotionally coping with such events has become a public health issue (Lowe, Blachman-Forshay, \& Koenen, 2015)

\section{Research Methodology}

The research aim was to analyse with which words the Covid 19 has been linked on newspapers article's titles in the month of March 2020. March month has been chosen because in this month the events overcame the global population and as it has been shown in the first part of this article the life of individuals, the everyday routine has been turned upside down. March month and the stress of the upheaval changes, of concern for both health and the economic situation was the month of infodemia.

Why the titles of the articles? Because it is the first line that attracts readers' attention on reading the title of the article, the customers can decide to proceed with the reading of the articles or to pass to another article or another newspaper. The title of the article should in few words say about what will be the article and arouse the reader's interest, the destiny of the article to be read or to be trashed depend on the title. Different researchers proposed different criteria for news to become the news. M. Reiter (2009: 21-27), as criteria for the selection of news, indicates the following: relevance when an event has just occurred or has only just become known about it; drama and disruption of the natural course of events; fun and something outstanding; 
exclusivity; utility; the geographical proximity; personal intimacy; emotional aspects; celebrities; sex; unambiguity, since black-and-white is preferable to undefined; duration when new information on a topic is being heard. Karol Rich (2010: 12-16) calls such criteria for selecting news: timeliness; proximity to the reader; unusual; dramatic; the conflict; relevance to the reader; utility; participation of celebrities; entertainment; worrying trends concerning the reader.

The first step has been the selection of countries, for to do this it was helpful the work done by Daniel Hallin e Paolo Mancini that after the analysis of the four main dimensions: development of media markets; political parallelism; development of journalistic professionalism; the extent and nature of state interference in media systems, according to which the media systems of Western Europe and North America can be successfully compared there are three models of mass-media

- the North Atlantic or liberal model (for the United Kingdom, Ireland, Canada and the United States of America) - characterised by the predominance of the logic of the market and of commercial media

- the Northern European or democratic corporatist model (in Austria, Belgium, Denmark, Finland, Germany, the Netherlands, Norway, Sweden, Switzerland) - characterised by a coexistence of a historical means of information in commercial and transport-related political groups, and a role of the State relatively active but legally limited;

- Mediterranean, or polarised pluralistic model (in France, Greece, Italy, Portugal, Spain).- characterised by the overlap between media and politics by a weak development of the media trade and strong intervention of the State

Was choose a country per ideal Hallin\&Mancini Model for the liberal model have been chosen the United Kingdom, for the democratic corporatist model, have been chosen Germany and for the polarised pluralistic model have been chosen Italy.

The second step was to choose the newspapers. The used principle of selection of newspapers was the place on the ranking, and the first place has been chosen so consequently from the UK have been chosen "The Sun", from Germany have been chosen the newspaper "Süddeutsche" and from Italy was chosen the newspaper "Il Corriere Della Sera".

The selection of titles of the articles was made by the google search engine Google, for the huge popular database that contains web sites indexed, and to be able to categorise in relation to the keywords, the results are indexed, and order of relevance is established from the most relevant to the most generic according to Google algorithms.

The research keyword was Coronavirus. On table 1 the obtained selection subdivided by newspapers 


\begin{tabular}{|c|c|c|}
\hline The Sun & “Süddeutsche" & $\begin{array}{l}\text { Il corriere della } \\
\text { Sera }\end{array}$ \\
\hline $\begin{array}{l}\text { "VIRAL SPREAD } \\
\text { Widespread coronavirus outbreak } \\
\text { across UK is 'highly likely', top health } \\
\text { official warns." }\end{array}$ & $\begin{array}{l}\text { Typical symptoms } \\
\text { of Covid-19 }\end{array}$ & $\begin{array}{l}\text { Coronavirus, the } \\
\text { latest news from } \\
\text { Italy and the world }\end{array}$ \\
\hline $\begin{array}{l}\text { "YOUR COUNTRY NEEDS YOU } \\
\text { The } 12 \text { things to do to keep you and } \\
\text { your family safe from Coronavirus." }\end{array}$ & $\begin{array}{l}\text { Too good to be } \\
\text { true }\end{array}$ & $\begin{array}{l}\text { Coronavirus, the } \\
\text { latest news from } \\
\text { Italy and the world }\end{array}$ \\
\hline $\begin{array}{l}\text { "HIGH ALERT } \\
\text { NHS declares highest-level emergency } \\
\text { as coronavirus cases hit } 51 \& \text { Boris } \\
\text { Johnson reveals battle plan." }\end{array}$ & $\begin{array}{l}\text { "Sorry, but I have } \\
\text { to } c r y " \text { - (Italy } \\
\text { cases) }\end{array}$ & $\begin{array}{l}\text { Coronavirus, the } \\
\text { latest news from } \\
\text { Italy and the world }\end{array}$ \\
\hline $\begin{array}{l}\text { "VIRUS EXPLOSION } \\
\text { Coronavirus cases in UK leap to } 87 \text { as } \\
\text { medical chief warns 'significant } \\
\text { epidemic likely' and Brits 'will die" ' }\end{array}$ & $\begin{array}{l}\text { Which path leads } \\
\text { out of the } \\
\text { epidemic? }\end{array}$ & $\begin{array}{l}\text { Coronavirus, the } \\
\text { latest news from } \\
\text { Italy and the world }\end{array}$ \\
\hline $\begin{array}{l}\text { "VIRAL LOAD } \\
\text { Volunteers to be infected with } \\
\text { Coronavirus for } £ 3,500 \text { in bid to find } \\
\text { vaccine." }\end{array}$ & $\begin{array}{l}\text { In the death zone - } \\
\text { (Italy cases ) }\end{array}$ & $\begin{array}{l}\text { Coronavirus, the } \\
\text { latest news from } \\
\text { Italy and the world }\end{array}$ \\
\hline $\begin{array}{l}\text { "GLOBAL ALERT } \\
\text { Coronavirus outbreak declared a } \\
\text { pandemic by WHO - after 'alarming } \\
\text { spread and severity of cases' in } 114 \\
\text { countries. }\end{array}$ & $\begin{array}{l}\text { The force of the } \\
\text { great number }\end{array}$ & $\begin{array}{l}\text { Coronavirus, the } \\
\text { latest news from } \\
\text { Italy and the world }\end{array}$ \\
\hline $\begin{array}{l}\text { BRACE YOURSELF } \\
\text { Millions in UK MUST catch } \\
\text { Coronavirus so we develop 'herd } \\
\text { immunity', says top scientist"' }\end{array}$ & $\begin{array}{l}\text { The clinical picture } \\
\text { of Covid-19 is a } \\
\text { chameleon. }\end{array}$ & $\begin{array}{l}\text { Coronavirus, the } \\
\text { latest news from } \\
\text { Italy and the world }\end{array}$ \\
\hline
\end{tabular}


Geopolitical, Social Security and Freedom Journal, Volume 3 Issue 2, 2020

\begin{tabular}{|c|c|c|}
\hline $\begin{array}{l}\text { "VIRUS ALERT } \\
\text { Coronavirus - UK death toll surges } \\
\text { from } 21 \text { to } 35 \text { overnight as a number } \\
\text { of cases hit } 1,391 "\end{array}$ & $\begin{array}{l}\text { They fight to the } \\
\text { point of exhaustion. }\end{array}$ & $\begin{array}{l}\text { Coronavirus, the } \\
\text { latest news from } \\
\text { Italy and the world }\end{array}$ \\
\hline $\begin{array}{l}\text { "LOCKDOWN NOW } \\
\text { Sun readers think Britain should be in } \\
\text { lockdown NOW over coronavirus } \\
\text { crisis." }\end{array}$ & $\begin{array}{l}\text { Does Europe's } \\
\text { "Patient } 0 \text { " come } \\
\text { from Bavaria? }\end{array}$ & $\begin{array}{l}\text { Coronavirus, the } \\
\text { latest news from } \\
\text { Italy and the world }\end{array}$ \\
\hline $\begin{array}{l}\text { "GONE VIRAL } \\
\text { Coronavirus could have 'already } \\
\text { infected HALF the population - and } \\
\text { it's been spreading since January"' }\end{array}$ & $\begin{array}{l}\text { Interior Ministry } \\
\text { urges massive } \\
\text { expansion of } \\
\text { Corona Tests. }\end{array}$ & $\begin{array}{l}\text { Coronavirus, the } \\
\text { latest news from } \\
\text { Italy and the world }\end{array}$ \\
\hline $\begin{array}{l}\text { "KILLER SPREAD } \\
\text { Italian coronavirus death toll soars to } \\
2,978 \text { with } 475 \text { in one day alone as } \\
\text { crisis spirals out of control." }\end{array}$ & $\begin{array}{l}\text { Always just } \\
\text { numbers that } \\
\text { unsettles. }\end{array}$ & $\begin{array}{l}\text { Coronavirus, the } \\
\text { latest news from } \\
\text { Italy and the world }\end{array}$ \\
\hline $\begin{array}{l}\text { "VIRUS STRIKES } \\
\text { Coronavirus kills one Brit every } 13 \\
\text { minutes as death toll soars to } 578 \text { with } \\
\text { pandemic claiming } 113 \text { lives in one } \\
\text { day." }\end{array}$ & $\begin{array}{l}\text { The city where the } \\
\text { bells no longer ring } \\
\text { (Italy cases ) }\end{array}$ & $\begin{array}{l}\text { Coronavirus, the } \\
\text { latest news from } \\
\text { Italy and the world }\end{array}$ \\
\hline $\begin{array}{l}\text { "VIRAL LOAD } \\
\text { Volunteers to be infected with } \\
\text { Coronavirus for } £ 3,500 \text { in bid to find } \\
\text { vaccine." }\end{array}$ & $\begin{array}{l}\text { In A State Of } \\
\text { Emergency }\end{array}$ & $\begin{array}{l}\text { Coronavirus, the } \\
\text { latest news from } \\
\text { Italy and the world }\end{array}$ \\
\hline $\begin{array}{l}\text { "CORONA CRISIS } \\
\text { Coronavirus Boris Johnson to declare } \\
\text { Britain has given up fight to contain } \\
\text { Virus as it's declared pandemic." }\end{array}$ & $\begin{array}{l}\text { Coronavirus: your } \\
\text { questions to our } \\
\text { knowledge editor: }\end{array}$ & $\begin{array}{l}\text { Coronavirus, the } \\
\text { latest news from } \\
\text { Italy and the world }\end{array}$ \\
\hline
\end{tabular}




\begin{tabular}{|c|c|c|}
\hline $\begin{array}{l}\text { "DEADLY SPREAD } \\
\text { Seven coronavirus cases traced back } \\
\text { to a single English football match by } \\
\text { scientists who found } 40 \text { mutations of } \\
\text { disease" }\end{array}$ & $\begin{array}{l}\text { Why Italy is so } \\
\text { badly affected }\end{array}$ & $\begin{array}{l}\text { Coronavirus, the } \\
\text { latest news from } \\
\text { Italy and the world }\end{array}$ \\
\hline $\begin{array}{l}\text { "EASTER CANCELLED } \\
\text { Coronavirus 'to peak over Easter with } \\
\text { thousands infected' and 'cause worst } \\
\text { holiday chaos since WW2', experts } \\
\text { warn." }\end{array}$ & $\begin{array}{l}\text { "I feel totally alone } \\
\text { here" (Italy cases) }\end{array}$ & $\begin{array}{l}\text { Coronavirus, the } \\
\text { latest news from } \\
\text { Italy and the world }\end{array}$ \\
\hline $\begin{array}{l}\text { "HOPE ON THE HORIZON } \\
\text { From vaccine trials to potential } \\
\text { treatment and recovery, the good } \\
\text { news amid coronavirus chaos." }\end{array}$ & $\begin{array}{l}\text { Better later than } \\
\text { earlier }\end{array}$ & $\begin{array}{l}\text { Coronavirus, the } \\
\text { latest news from } \\
\text { Italy and the world }\end{array}$ \\
\hline $\begin{array}{l}\text { "INTO THE ABYSS } \\
\text { "Sharp rise" in UK coronavirus cases } \\
\text { as two more dead ant total explodes to } \\
596 . "\end{array}$ & $\begin{array}{l}\text { The Corona-crisis, } \\
\text { disenchanted with } \\
\text { the populists }\end{array}$ & $\begin{array}{l}\text { Coronavirus, the } \\
\text { latest news from } \\
\text { Italy and the world }\end{array}$ \\
\hline $\begin{array}{l}\text { "STEALTH SPREAD } \\
\text { Growing fears people without } \\
\text { coronavirus symptoms are spreading } \\
\text { Covid-19." }\end{array}$ & $\begin{array}{l}\text { Pandemic of half- } \\
\text { truths }\end{array}$ & $\begin{array}{l}\text { Coronavirus, the } \\
\text { latest news from } \\
\text { Italy and the world }\end{array}$ \\
\hline $\begin{array}{l}\text { "YEAR OF CHAOS? } \\
\text { UK coronavirus crisis may last a } \\
\text { YEAR and leave } 7.9 \text { million patients } \\
\text { in hospital, leaked health report } \\
\text { warns." }\end{array}$ & $\begin{array}{l}\text { Typical symptoms } \\
\text { of Covid-19 }\end{array}$ & $\begin{array}{l}\text { Coronavirus, the } \\
\text { latest news from } \\
\text { Italy and the world }\end{array}$ \\
\hline
\end{tabular}

Analysing the data is possible to see that titles of articles overturn the theory of interactionist language development. The three countries with a stereotype of their inhabitants, for sure the UK and Germany inhabitants are to be considered more reserved and even a little "cold" than the inhabitants of Italy. Analysing the data is possible to note that in The Sun titles is possible to note in media two with high 
emotive impact words per title. These words are: die, death, chaos, abysses, explosion, explodes, killer, kills, brace yourself, high, global and Virus alert.

In the German newspaper titles there are a few words with high emotive impact and almost of this titles are connected with Coronavirus situation in Italy there where some metaphorical phrases like "The city where the bells no longer ring" or "In the death zone" the words with the emotive weight were: cry, death, exhaustion, badly affected, alone, crisis.

The case of Italian newspaper was significant because the titles seem to not contain the words with an emotive impact but the idea that the numbers of heal people and of the dead people in Italy and in the world could have an emotive impact because the title creates an expectation of discovery of disturbing numbers The numbers that describe the Coronavirus weigh: the numbers of the infected in the world, the numbers of the dead these numbers weigh like lead. This numbers entered in each Italian house every day, they were a matter of discussion and could leave devastated individuals like an emotive high impact word.

The articles that respect quite totally the Carol rich criteria are the articles of The Sun, and in fact, the titles reflect the timeliness all three newspapers have news that is timely to the situation.

Respect of criteria: proximity to the reader and relevance to the reader utility the all three newspapers news are connected with the reader interest ( to have news about the Coronavirus in the country and in the world)

The criteria like dramatic; worrying trends concerning the reader were respected totally by the titles of the Sun partially by the Süddeutsche and not by Corriere Della sera but as it was told the expectance of new increased numbers can be dramatic and can reflect the worrying trends concerning the reader.

There is no participation of celebrities, and no entertainment as the keywords was Coronavirus

\section{Conclusions}

The year 2020 is the year of pandemic. The word" pandemic", which comes from the Greek and whose meaning is "all / all the people", is a heavy word because it warns individuals, from the beginning, that no one is safe. The mass media plays a huge role not only on informing people but also on how this information can be carried. In the pandemic situation was noted a large volumes of information and a big audience. Despite the voice of emotion is very strong in modern communication especially in mediated communication the emotional weight of the used words are not considered. There are a lot of researchers focused on investigation of what is the psychological effects of terrorism events or mass shooting illustrated on Twitter through using sentiment analysis (Azizan \& Aziz, 2017, Demszky et al., 2019; Jones et al., 2019) but a few reseaches has stressed the weight of the words used in massmedia and which effect it can have on individuals. The results of this research shows that if we use the theory of Binet that says that before the formulating of the word there is the imagination of the world then is possible to state that the images of the titles are macabre one.

This research aimed to show that mass-media can be a source of distress and the words can be as a bullets 


\section{References}

Azizan, S. A., \& Aziz, I. A. (2017). Terrorism detection based on sentiment analysis using machine learning. Journal of Engineering and Applied Sciences, 12(3), 691-698. https://doi.org/10.36478/jeasci.2017.691.698.

Demszky, D., Garg, N., Voigt, R., Zou, J., Shapiro, J., Gentzkow, M., et al. (2019). Analyzing polarization in social media: Method and application to tweets on 21 mass shootings. Proc. of the 2019 conf. of the North American chapter of the association for computational linguistics: Human language technologies (NAACL-HLT)2970-3005

Du, Z., Wang, L., Cauchemez, S., Xu, X., Wang, X., Cowling, B. J....Meyers, L. (2020). Risk for Transportation of Coronavirus Disease from Wuhan to Other Cities in China. Emerging Infectious Diseases,26(5), 1049-1052. https://dx.doi.org/10.3201/eid2605.200146.

Jones, N. M., Brymer, M., \& Silver, R. C. (2019). Using big data to study the impact of mass violence: Opportunities for the traumatic stress field. Journal of Traumatic Stress, 32(5), 653663.

Pinker, S. (2011). Words and Rules (1999/2011), New York, NY: Harper Perennial.

\section{Web references}

https://www.who.int/emergencies/diseases/novel-coronavirus-2019/advice-for-

public/when-and-how-to-use-masks

https://www.ecdc.europa.eu/en/covid-19/timeline-ecdc-response

https://yougov.co.uk/covid-19 